\title{
Ali Ünişen
}

Adıyaman University, aunisen@adiyaman.edu.tr, Adıyaman-Turkey Betül Demirbağ

Gazi University, demirbagbetul@gmail.com, Ankara-Turkey

http://dx.doi.org/10.12739/NWSA.2016.11.2.1C0653

\section{ORTAOKUL ÖĞRENCILERINNE VANDALİMIN AİLE İLİŞKİLERI VE BAZI DEĞİŞKENLER} AÇISINDAN INCELENMESİ (ADIYAMAN ILI ÖRNEĞİ)

\begin{abstract}
öz
Vandalizm içinde sergilendiği fiziki çevreye verilen maddi hasarla ekonominin, uygun öğrenme ortamının sabotajıyla eğitimin, hazırlayıcı sebepler ve sonuçlarıyla psikoloji ve sosyolojinin ve bunlarla eş zamanlı olarak kriminolojinin çalışma alanıdır. Bu interdisipliner olgunun ilişkili olduğu değişkenlerin tespiti önleyici rehberlikte alınacak tedbirler alınmasına dolayısıyla öğrenme ortamlarının korunmasına katkı sağlayacaktır. Bu çalışmada ortaokul öğrencilerinde vandalizmin aile ilişkileri, Tv ve bilgisayar kullanım süresi, okulun yapısı, sınıf düzeyi ve ailenin aylık ortalama gelir düzeyi bakımından araştırılması amaçlanmıştır. Çalışma, Adıyaman ilinde üç farklı ortaokulda gerçekleştirilmiş, vandalizmin ölçülmesinde Oruç (2008) tarafından geliştirilen 28 maddelik Okul Tahripçiliği Ölçeğinden ve aile ilişkilerinin belirlenmesinde Demirtaş Zorbaz ve Korkut Owen (2013) tarafından geliştirilmiş 20 maddelik Aile İlişkileri Ölçeğinden faydalanılmıştır. Bulgular, vandalizmin okulun yapısı, ailelerin ortalama aylık gelir düzeyi, algılanan aile ilişkileri ve Tv kullanım süresi bakımından farklılaştığını, bilgisayar kullanım süresinin ise anlamlı bir fark yaratmadığını ortaya koymaktadır.
\end{abstract}

Anahtar Kelimeler: Vandalizm, Ortaokul Öğrencileri, Aile İle İlişkiler, Televizyon, Bilgisayar

\section{AN EXPLORATION OF VANDALISM IN SECONDARY SCHOOL STUDENTS IN RESPECT TO FAMILY RELATIONS AND CERTAIN VARIABLES (ADIYAMAN CASE)}

\section{ABSTRACT}

Vandalism has been within the research interest of economy due to damage to the environment in which it was displayed, of education due to its threat to the proper learning atmosphere, of psychology and sociology with reasons preparing and fostering it as well as the its results. Furthermore, it is of concern of criminology concurrently, yet independently. Determination of the variables related to vandalism will contribute to taking preventive measures hence maintain the learning environments. Present study explores the vandalism in secondary school students in respect to family relations, time allotted to computer using and watching television, the school type attended, class level and average income of the family. The study was carried out at three various secondary school in Adiyaman. For data collection, School Vandalism Scale, consisted 28 items and developed by Oruç (2008), and Family Relations Scale, consisted of 20 items and developed by Demirtaş Zorbaz and Korkut Owen (2013) were used. Findings indicate that vandalist dispositions differ in respect to type of school, average income of the family, perceived family relations and the time allotted to watching tv but not differ significantly in respect to the time allotted to using computer.

Keywords: Vandalism, Secondary School Students, Family Relations, Television, Computer 


\section{GIRIŞ (INTRODUCTION)}

Vandalizm, en genel anlamıyla kasıtıı olarak ve bir amaç gütmeksizin savunmasız eşyaya zarar vermek olarak tanımlanabilir (Goldstein, 1996:19-20). Çoğunlukla mülkiyeti kamuya ait mallara yönelik olduğundan vandalizm Amerika ve Avrupa'da öncelikle ekonomiye yönelttiği tehditlerle ilgi alanı olmuştur. Maliyetinin hasar gören malın fiyatı, tamiri veya yeniden inşası, korunmasında alınan ekstra tedbirler ve benzer malların sigortasının yükselmesi gibi etmenlerle hesaplanmasından dolayı eğitimcilerden önce ekonomistlerin dikkatini çekmiştir (Kaiser, 1972). 1960'lardan sonra ise özellikle sosyopolitik bazl gelişmelerin de etkisi ile popüler bir inceleme konusu haline gelmiş (Arceneaux, 1976; Stretton, 1977), 1980'li yıllarda pek çok araştırmaya konu olmuştur. Bu konuda, psikoloji alanında yapılan araştırmalar vandalıı̆ın ve vandalizm'in nedenlerini ve belirleyicilerini saptamak üzerine yoğunlaşmıştır (Couture, 1983; Goldstein, 1996; Jimerson and Furlong, 2006).

Macario, Marquez ve Ramos (2004) toplu taşıma araçlarını tercih etme, açık havada yürüme ya da seyahat etmeye etki eden vandalizmi araştırırken ya da Austin ve Sanders (2007) Grafiti yazıları bulunan mekânların bireylerin güvendelik algısına ilişkin etkilerini saptamaya çalışırken bu disiplinler arası etki alanını örneklemişlerdir. Kişilerin dinlenme alanları ile vandalizm ilişkisini konu alan araştırmalar (Reade, 1982) ile kütüphanelere ve dolayısıyla kitaplara zarar verme şeklinde ortaya çıkan zararı ve olası önlemleri ortaya koymayı amaçlayan araştırmalar (Brown-Syed and Owens, 2011) da bu konu alanına yapılmış diğer önemli katkılardır. Etnik köken farklılıklarının incelendiği bir çalışmada Hispanik öğrencilerde ailede madde bağımlılığı öyküsü ya da düşük kabul algısı, Afro Amerikalı öğrencilerde aile içi iletişimsizlik, Hispanik olmayan beyaz grupta ise ailede düşük kabul algısı vandalizmle ilişkili bulunmuştur (Taylor, 1997). Ancak vandalizm sadece psikolojinin konu alanına girmeyecek kadar derin bir konudur; ekonomi, siyaset, yönetim, politika, kriminoloji, sosyoloji, sanat gibi pek çok disiplin alanını da yakından ilgilendirmekte (Owinyo, 2006), okullarda vandalizm ise tüm bu disiplinlerin ortak bahçesinden beslenmektedir.

Okullarda vandalizm ile ilgili yapılan araştırmalarda okul yönetiminin etkileri, öğretmenlerle ilgili faktörler, okula aidiyet, okulun genel iklimi, gelişim özellikleri gibi konular üzerinde durulduğu görülmektedir (Flemington, 1994; Mayer, 1983). Yine okullarda vandalizm ile önemli ölçüde ilişkili olan diğer bir kavram da aile örüntüleridir. Ceccato (2008) Estonya, Litvanya ve Letonya'da gerçekleştirdiği araştırmasında vandalizm'in bölgesel yoğunlaşma haritasını oluşturmuş ve özellikle dağılmış ailelerin bulunduğu yerlerde daha yoğun görüldüğünü kaydetmiştir. Yine Ceccato (2008)'nun Mahoney ve Stattin'den aktardığına göre bu durum "genç gruplar için bir eğlenme şekli" halini almıştır. Okul İklimi ile şiddet-vandalizm arasındaki ilişkiyi irdeleyen Massey (1997), okul ikliminin, beklentilerin aksine, vandalizmi yordamada anlamlı düzeyde etkili olmadığını saptamıştır. Bununla beraber ulusal kapsamlı araştırmalardan birinde, Doğan ve Demir (2012)'in Sincan ilçesinde 1246 öğrenci üzerinde gerçekleştirdikleri bir çalışma sonucunda bu iki değişken arasında düşük düzeyde negatif korelasyon saptandığı gözlenmektedir. Vandalizme ilişkin öğretmen görüşlerini inceleyen Yavuzer (1998), öğretmenlerin Vandalizm'in nedenlerini değerlendirirken muhafazakar görüşü, çözüm önerileri ve ülke çapında tedbirler alınması hususunda ise liberal görüşü benimsediklerini saptamıştır. Vandalizm ile ilgili uluslararası çalışmalar, olgunun nozolojisi üzerine yoğunlaşmakta; çevresel faktörlerin, kültürel 
etmenlerin, düşünce türlerinin, ideolojilerin ve etnik köken farklılıklarının altını çizmektedirler. Anne baba etkisi, aile içi iletişim ve atmosfer ve kişinin ailedeki kabul ediliş düzeyi de ayrıca vurgulanan değişkenler arasındadır (Kaiser, 1972; Medley, 1985). Hem ulusal hem uluslararası alanyazında sosyo ekonomik düzeyle vandalizm arasında bir ilişkinin varlığına dair bir görüş birliğine varılabilmiş değildir. Ulusal çalışmaların sayıca azlığı ve vandalizmle ilişkili değişkenlerin bilinmemesi bu bağlamda önemli bir problemin çözümlenmesinin önünde en büyük engeli oluşturmaktadır. Bu araştırmanın, ilgili literatüre katkı getirmenin yanısıra yıkıcı davranışlarca tüketilmekte olan milli servetin korunmasına ilişkin öneriler geliştirilmesinde ve vandalizm davranışının nedenlerini tespit etmede etkili bir adım olacağı düşünülmektedir. Bu araştırmayla bir sınıftaki öğrecilerin vandalist davranışlarda bulunmaları ile aile ilişkileri, sınıf düzeyi, tv ve bilgisayarda geçirilen süre arasında anlamlı ilişki olup olmadığının ve aile ilişkilerine ilişkin algllarının tv izleme süresi/bilgisayar kullanım süresine göre anlamlı farklılık gösterip göstermediğinin saptanması amaçlanmaktadır. Bu amacı gerçekleştirmek için aşă̆ıdaki alt amaçlar gözetilmiştir.

- Öğrencilerin vandalist davranışları sınıf düzeylerine göre anlamlı farklılık göstermekte midir?

- Öğrencilerin vandalist davranışları okullarının kırsal/merkezi oluşuna göre anlamlı farklılık göstermekte midir?

- Öğrencilerin vandalist davranişlar sergilemeleri aileilerinin aylık ortalama gelirine göre farklılık göstermekte midir?

- Öğrencilerin vandalist davranışlar sergilemeleri, algıladıkları aile ilişkilerine göre anlamlı farklılık göstermekte midir?

- Öğrencilerin vandalist davranişlar sergilemeleri günlük tv izleme sürelerine göre farklılık göstermekte midir?

- Öğrencilerin vandalist davranışlar sergilemeleri günlük bilgisayar kullanım sürelerine göre farklılık göstermekte midir?

- Öğrencilerin aile ilişkilerini destekleyici olarak algılama durumları günlük tv izleme sürelerine göre farklılaşmakta mıdır?

- Öğrencilerin aile ilişkilerini destekleyici olarak algılama durumları günlük bilgisayar kullanım sürelerine göre farklılaşmakta mıdır?

\section{2. ÇALIŞMANIN ÖNEMI (RESEARCH SIGNIFICANCE)}

Aynı alanda yapılan ancak bulguları arasında fikir birliği bulunmayan uluslararası alan yazın ve konuyla ilgili ulusal düzeydeki araştırmaların nispeten azlığı vandalismin daha fazla çalışmayla aydınlatılmaya ihtiyaç duyduğunu göstermektedir. Bu araştırmanın, bu iki açıdan alanyazına katkı sağlarken, ülkenin eğitim ekonomisine, daha olumlu öğrenme ortamlarının oluşturulmasına yönelik tedbirlerin alınmasına da yardım edeceği düşünülmektedir.

\section{YÖNTEM (METHOD)}

3.1. Araştırma modeli (Research Model)

Bu araştırmada öğrencilerin vandalist davranışlar göstermeleri sosyo-ekonomik düzey, sınıf düzeyi ve Televizyon/Bilgisayarda geçirilen süre bakımından ele alınmış, davranışın aile ilişkileri ile ilişkisi incelenmiştir. Bu amaçla, ilişkisel araştırma düzeneği kullanılmıştır.

\subsection{Evren ve Örneklem (Population and Sample)}

Araştırmanın evrenini Adıyaman ilinde öğrenim gören tüm ortaokul öğrencileri oluşturmaktadır. İlgili literatür, okulun kırsal-kentsel 
bölgede yer alması, büyüklüğü ve yeni öğretmen oranının fazlalığı gibi etmenler ile vandalizm arasında manidar bir ilişki olduğuna işaret etmektedir (Bower, 1976; Plavnic, 1983; Stretton, 1977). Dolayısıyla okulun yer aldığı bölge ve okul büyüklüğü, araştırma sonuçlarını etkileme ihtimaline karşı kontrol altına alınması gereken değişkenlerdir. Bu amaçla, tabakalı örnekleme metoduna başvurulmuştur. Tabakalı örnekleme, evren bağımlı değişkeni etkileyebilecek potansiyel alt evrenlerden oluştuğunda kullanılan bir tekniktir ve bu örnekleme metodu sayesinde karıştırıcı değişkenlerin etkisini devre dışı bırakmak mümkün olmaktadır (Erkuş, 2013). Metoda uygun olarak seçilen üç okulun özellikleri şu şekildedir:

- Okul 1: Kendi yakın çevresinden öğrenci alan, daha az sayıda ve homojen öğrenci yapısında sahip, düşük sosyoekonomik düzeyli

- Okul 2: Karışık bir çevreden öğrenci alan, görece daha heterojen bir öğrenci nüfusuna sahip, orta sosyoekonomik düzeyli

- Okul 3: Geniş bir çevreden öğrenci alan, heterojen öğrenci yapısına sahip, popüler ve üst sosyo-ekonomik düzeyli

Toplam 401 öğrenci ile çalışılmış, hatalı/eksik doldurulan ölçekler çıkarılarak 376 kişilik nihai örneklem grubuna ulaşılmıştır. Benzer şekilde bu sınıflarda ders veren öğretmenlerden 96 kişilik veri grubuna ulaşılmış, analizler sonrasında eksik ve hatalı doldurulanlar dışında tutularak 89 kişilik çalışma grubu elde edilmiştir.

\subsection{Veri Toplama Araçları (Instrumentation)}

Verilerin toplanmasında Çocuklar için Aile İletişim Ölçeği, okul Tahripçiliği Ölçeği ve araştırmacılar tarafından geliştirilmiş olan kişisel bilgi formu kullanılmıştır.

\subsection{1. Çocuklar için Aile İlişkileri ölçeği (Family Relations Scale for Children)}

Demirtaş Zorbaz ve Korkut Owen (2013) tarafından 4 ve 5. Sınıf öğrencileri için geliştirilmiş olan ölçek, çocukların aile işlevlerini nasıl algıladıklarını ölçmektedir. 20 maddelik, iki faktörlü ölçek "engelleyici aile ilişkileri" ve "destekleyici aile ilişkileri" alt boyutlarını içermekte, her bir altboyut 10'ar maddeden oluşmaktadır. Demirtaş Zorbaz ve Korkut Owen tarafından gerçekleştirilen çalışmada madde yük değerleri .46 ile .69 arasında değişmektedir. Üçlü likert tipinde hazırlanmış ölçekte öğrenciler her zaman, bazen ve hiçbir zaman seçeneklerinden kendilerine uygun olanı işaretlemektedir. Demirtaş Zorbaz ve Korkut Owen (2013) ölçeğin alt boyutlar için bir toplam puan hesaplamasına olanak verse de genel bir toplam puanı olasılıklı kılmadığını ifade etmektedir. ÇAïönnün cronbach alfa katsayısı, orijinal çalışmada iki ayrı grup için, birinci alt boyut için .83 ve .84 ve ikinci alt boyut için .76 ve .78 olarak, bu çalışmada ise birinci altboyut için .77 ve ikinci altboyut için .60 olarak belirlenmiştir (Teknik bilgi atırılmalı).

\subsubsection{Okul Tahripçiliği ölçeği (School Vandalism Scale)}

Oruç (2008) tarafından geliştirilen 28 maddeden oluşan ölçek tek boyutlu bir yapıya sahiptir. Ölçek, öğrenci, yönetici ve öğretmenlere uygulanabilmektedir. Toplam 917 katılımcı ile gerçekleştirdiği araştırmasında Oruç (2008), analizler sonrasında bu üç grup içinde en duyarlı bilginin öğretmenlerden alınabileceğini rapor etmektedir. Madde faktör yük değerleri Oruç tarafından .43 ile .76 arasında rapor edilen ölçeğin güvenirlik analizi sonucunda Cronbach Alpha güvenirlik katsayısı, orijinal çalışmadaki .92 değerine paralel olarak .90 olarak belirlenmiştir (Teknik bilgi artırılmalı). 


\subsubsection{Kişisel Bilgi Formu (Personal Information Form)}

Katılımclların cinsiyeti, sınıf düzeyi, sosyo-ekonomik düzeyi ile günlük televizyon ya da bilgisayar kullanım süresini içermektedir.

\subsection{Verilerin Toplanması (Data Collection)}

Araştırmada Aile ilişkileri ölçeği ile kişisel bilgi formu, öğrencilere yöneltilmiş ve Okul tahripçiliği ölçeğinde öğretmen görüşlerinden faydalanılmıştır. Oruç (2008) çalışmasında öğretmen, öğrenci ve yöneticilerle gerçekleştirdiği çalışmada gerçeklerle en büyük oranda örtüşen sonuçların öğretmen gözlemlerine dayalı okul tahripçiliği ölçeğinden elde edildiğini rapor etmektedir. Ayrıca ölçekteki soruların bireyin kendisini hariç içinde bulunduğu sınıfı değerlendirmeye yönelik olması, bu çalşmada okul tahripçiliğine ilişkin algıyı öğretmen gözlemlerinden elde etme girişimimize temel dayanak noktasını oluşturmaktadır. Uygulamada ortaokul öğrencilerinden her sınıf düzeyinde bir sınıf olacak şekilde üç ayrı okuldan veri toplanmıştır. Oruç (2008:62), okulda tahripçi davranışlara en fazla şahit olanların yönetici ve öğrencilere kıyasla öğretmenler olduğunu belirtmektedir. Bu sebeple öğrencilerden elde edilen aile ilişkileri ile karşılaştırmak üzere, okul tahripçiliği ölçeğini söz konusu sınıfı göz önüne alarak değerlendirmeleri, sınıfın öğretmenlerinden istenmiştir. Elde edilen bulgular ışığında her sınıfa ilişkin öğretmen gözlemlerinin ortalaması alınmış ve bütün sınıflar için ayrı ayrı alınan tüm gözlemlerin ortalaması baz alınarak belirlenen kesme noktasıyla elde edilen değer düşük vandalist davranışlar/ yüksek vandalist davranışlar gözlenen sınıf olarak yapay kesikli hale getirilmiştir.

\subsection{Verilerin Çözümlemesi (Data Analysis)}

Araştırmada elde edilen verilerin çözümlenmesinde SPSS 21.0 paket programından faydalanılmış, artimetik ortalama, standart spama, bağımsız gruplar t testi, tek yön anova, ki kare analizi ve güvenirlik analizi hesaplamaları gerçekleştirilmiştir.

\section{BULGULAR (FINDINGS)}

\subsection{Katılımcılara İlişkin Demografik Bilgiler} (Demografic Details of the Participants)

Tablo 1'de katılımciların okullarına, cinsiyetlerine ve sınıf düzeylerine göre dağılım ve yüzdelerine yer verilmiştir. Tabloda da görüldüğü gibi araştırma için cinsiyet, okul ve sınıf düzeyi bazında dengeli bir dağılım gözetilmiştir.

Tablo 1. Katılımcılara yönelik demografik bilgiler

(Table 1. Demographic details of participants)

\begin{tabular}{|c|c|c|c|}
\hline & Gruplama & $\mathrm{N}$ & $\frac{0}{0}$ \\
\hline \multirow{4}{*}{ Okul } & Okul 1 & 127 & 33,8 \\
\hline & Okul 2 & 114 & 30,3 \\
\hline & Okul 3 & 135 & 35,9 \\
\hline & Toplam & 376 & 100,0 \\
\hline \multirow{3}{*}{ Cinsiyet } & Kız & 217 & 57,7 \\
\hline & Erkek & 159 & 42,3 \\
\hline & Toplam & 376 & 100,0 \\
\hline \multirow{5}{*}{ Sınıf } & 5. slnıf & 94 & 25,0 \\
\hline & 6. slnıf & 91 & 24,2 \\
\hline & 7. sinlf & 94 & 25,0 \\
\hline & 8. slnif & 97 & 25,8 \\
\hline & Toplam & 376 & 100,0 \\
\hline
\end{tabular}




\subsection{Birinci Alt Amaca İlişkin Bulgular (Findings Dealing with the First Sub-objective) \\ Tablo 2'de öğrencilerin vandalist davranışlarına ilişkin öğretmen değerlendirmesinde sınıf düzeyi değişkeni bakımından ortalama, standart sapma değerleri ve Bonferonni testi kapsamında varyans analizi anlamlılık sonuçlarına yer verilmiştir. Analizler gerçekleştirilmeden önce, verilerin varyans analizine uygunluğu için varyansların homojenliği varsayımı test edilmiştir.}

Tablo 2. Öğrencilerin vandalist davranışlarına ilişkin öğretmen gözlemleri kapsamında sınıf düzeyi değişkeninin incelenmesine yönelik tek yönlü varyans analizi

(Table 2. One-way anova results of teachers' observations related to students' vandalist dispositions according to class levels)

\begin{tabular}{|c|c|c|c|c|c|c|}
\hline Siniflar & $\mathrm{n}$ & $\overline{\mathrm{X}}$ & SS & F & $\mathrm{P}$ & Anlamlılık (Bonferonni) \\
\hline 5. Sınıf & 22 & 70,04 & 12,29 & \multirow{5}{*}{.305} & \multirow{5}{*}{.821} & \multirow{5}{*}{-} \\
\hline 6. Sınıf & 20 & 72,30 & 13,03 & & & \\
\hline 7. Sınıf & 23 & 70,08 & 13,90 & & & \\
\hline 8. Sınıf & 24 & 68,25 & 16,07 & & & \\
\hline Toplam & 89 & 70,07 & 13,81 & & & \\
\hline
\end{tabular}

Tablo 2'de de görüldüğü gibi 6. Sınıf ortalaması $(\overline{\mathbf{X}}=72,30) 5$. Sinıf $(\overline{\mathrm{X}}=70,04), \quad 7$. Sinıf $(\overline{\overline{\mathrm{X}}}=70,08)$ ve 8 . Sinıf $(\overline{\mathrm{X}}=68,25)$ ortalamalarından yüksek olmakla beraber aradaki fark $\mathrm{p}<.05$ düzeyinde anlamlı değildir $(\mathrm{F}=.305 ; \mathrm{P}=.821)$

\section{3. İkinci Alt Amaca İlişkin Bulgular} (Findings Dealing with the Second Sub-objective)

Tablo 3'te öğrencilerin Vandalist davranışlar sergilemelerinde okul değişkenine ilişkin anlamlı farklılık olup olmadığı araştırılmıştır. Analizler gerçekleştirilmeden önce, verilerin varyans analizine uygunluğu için varyansların homojenliği varsayımı test edilmiştir.

Tablo 3. Vandalist davranışların gözlenme sıklığına ilişkin okul bazlı varyans analizi

(Table 3. Variance analysis of frequency of vandalist dispositions observed according to school type)

\begin{tabular}{|c|c|c|c|c|c|c|}
\hline Okullar & $\mathrm{N}$ & $\overline{\mathrm{X}}$ & $\mathrm{SS}$ & $\mathrm{F}$ & $\mathrm{P}$ & Anlamlılık(Bonferonni) \\
\hline Okul 1 & 26 & 65,11 & 14,89 & & & \\
\cline { 1 - 3 } Okul 2 & 28 & 74,78 & 12,21 & \multirow{3}{*}{3,49} & $.035 *$ & $(1-2)$ \\
\hline Okul 3 & 35 & 70,00 & 13,22 & & \\
\hline Toplam & 89 & 70,07 & 13,81 & & & düzeyinde anlamlıdır \\
\hline
\end{tabular}

Tablo 3'de de görüldüğü üzere en yüksek ortalamaya okul 2, $(\bar{X}=74,78) \quad$ karışık bir havzadan öğrenci alan orta sed düzeyine sahip okul sahiptir. Bu okulu $(\overline{\mathrm{X}}=70,00)$ ortalamayla yüksek sosyo ekonomik düzeye sahip, öğrencilerin heterojen bir havzadan alındığı okul 3 ve son olarak $(\overline{\mathbf{X}}=65,11)$ ortalamayla kendi havzasından öğrenci alan okul 1 izlemektedir.

\section{4. Üçüncü Alt Amaca İlişkin Bulgular} (Findings dealing with the First Sub-objective)

Tablo 4'te öğrencilerin vandalist davranışlar sergilemelerinde ailelerinin geliri bakımından farklılaşma olup olmadığı araştırılmış, 
bu amaçla öğrenciler gelir bakımından 0-1000, 1000-3000 ve 3000+ olarak üç gruba ayrılmışlardır. Aradaki farkı test etmek için Ki Kare testi uygulanmıştır.

Tablo 4. Öğrencilerin ailelerinin aylık ortalama gelir dağılımına göre vandalist davranışlar sergileme durumlarına ilişkin ki kare testi sonuçları

(Table 4. Chi Square test results related to vandalist disposition of students according to avarage family income)

\begin{tabular}{|c|c|c|c|c|}
\hline & $\begin{array}{l}\text { Vandalist } \\
\text { davranışlar düşük }\end{array}$ & $\begin{array}{l}\text { Vandalist } \\
\text { davranışlar yüksek }\end{array}$ & Top. & $\mathrm{P}$ \\
\hline $0-1000$ arası & $86 \quad(\div 45)$ & $58 \quad(\div 32)$ & 144 & \multirow{4}{*}{$.04 *$} \\
\hline $1000-3000$ aralığı & $72(\div 38)$ & 92 (51) & 164 & \\
\hline 3000 ve fazlası & $33(\div 17)$ & $29\left(\frac{0}{\circ} 16\right)$ & 62 & \\
\hline Toplam & 191 & 179 & 370 & \\
\hline
\end{tabular}

*Gruplararası fark p<.05 olduğundan, fark anlamlıdır

Tablo incelendiğinde, vandalist davranışların aylık geliri $1000-$ 3000 bandında dağılan ailelerin çocuklarında diğerlerine göre belirgin düzeyde daha yüksek vandalist davranışlar sergiledikleri gözlenebilir. Paralel şekilde, aylık geliri 0-1000 arası olan ailelerin çocukları diğer çocuklara kıyasla daha az vandalist davranışlar sergilemektedirler. Ki kare analiz sonuçları, aradaki fark p<.05 olduğundan anlamlı olduğuna işaret etmektedir.

\subsection{Dördüncü Alt Amaca İlişkin Bulgular (Findings Dealing with the Fourth Sub-objective)}

$\mathrm{Bu}$ alt amaçta öğrencilerin vandalist davranışlar sergilemelerinde ailelerine ilişkin algılarının belirleyici olup olmadığı araştırılmış, bu amaçla öğrencilerin engelleyici aile ve destekleyici aile puanları ile vandalist davranışlar sergileme durumları bağımsız örneklemler için $t$ testi kullanılarak incelenmiştir.

Tablo 5. Öğrencilerin vandalist davranışlar sergileme durumlarının algıladıkları aile ilişkisi bakımından incelenmesi

(Table 5. Students's vandalist dispositions according to the perceived family relations)

\begin{tabular}{|l|l|c|c|c|c|c|}
\hline & $\begin{array}{l}\text { Vandalist Davranışlarda } \\
\text { Bulunma Durumu }\end{array}$ & $\mathrm{N}$ & $\overline{\mathrm{X}}$ & $\mathrm{SS}$ & $\mathrm{F}$ & $\mathrm{P}$ \\
\hline $\begin{array}{l}\text { Engelleyici } \\
\text { Aile }\end{array}$ & Düşük & 186 & 14,84 & 2,657 & .626 & $.031^{\star}$ \\
\cline { 2 - 7 } & Yüksek & 175 & 14,30 & 2,840 & & \\
\hline $\begin{array}{l}\text { Destekleyici } \\
\text { Aile }\end{array}$ & Düşük & 190 & 25,88 & 3,074 & 1.096 & $.017^{\star}$ \\
\cline { 2 - 5 } & 176 & 26,61 & 3,402 & & \\
\hline
\end{tabular}

*Gruplar arası fark p<.05 düzeyinde anlamlıdır

Tablo 5'te vandalist davranışlarda bulunma sıklığının yüksek veya düşük olmasının, öğrencilerin ailelerini engelleyici veya destekleyici olarak algılamalarında belirleyici olduğu saptanmış, aradaki fark her iki altboyut için anlamlı bulunmuştur. Buna göre, düşük düzeyde vandalist davranışlarda bulunan çocukların ailelerini engelleyici olarak algllama ortalamaları $(\overline{\mathrm{X}}=14,84)$ yüksek düzeyde olanların ortalamalarına $(\overline{\mathbf{X}}=14,30)$ göre daha fazladır ve aradaki fark anlamlıdır. Yüksek düzeyde vandalist davranışlarda bulunan çocukların ailelerini destekleyici olarak algılama ortalamaları $(\overline{\mathbf{X}}=26,61)$ düşük düzeyde olanların ortalamalarına $(\overline{\mathrm{X}}=25,88)$ yüksektir ve aradaki fark anlamlıdır. Özetle destekleyici ailelerin çocukları ve engelleyici 
ailelerin çocukları diğerlerinden daha fazla vandalist davranışlar sergilemektedirler.

\subsection{Beşinci Alt Amaca Yönelik Bulgular (Findings Dealing with the Fifth Sub-objective)}

Tablo 6'da öğrencilerin vandalist davranışlar sergilemelerinde günlük tv izleme süreleri bakımından bir farklılık olup olmadığı test edilmiş, yapılan ki kare analizi sonrasında şu bulgulara ulaşılmıştır.

Tablo 6. Günlük Tv izleme süresi bakımından vandalist davranışların gözlenme frekansına ilişkin ki-kare tablosu

(Table 6. Chi Square test results related vandalist dispotions according to the time allotted to watching television)

\begin{tabular}{|c|c|c|c|c|c|}
\hline & Süre & $\begin{array}{l}\text { Vandalist } \\
\text { davranışlar } \\
\text { düşük }\end{array}$ & $\begin{array}{l}\text { Vandalist } \\
\text { davranışlar } \\
\text { yüksek }\end{array}$ & Top. & $P$ \\
\hline \multirow{4}{*}{$\begin{array}{l}\text { TV izleme } \\
\text { süresi }\end{array}$} & 1 saatten az & $70 \quad(\div 36,5)$ & $80 \quad(\div 43,7)$ & 150 & \multirow{4}{*}{$\star .041$} \\
\hline & 1-4 saat arası & $108 \quad(\div 56,3)$ & $99 \quad(\div 54,1)$ & 207 & \\
\hline & 4 saatten fazla & $14(\div 7,3)$ & $4 \quad(\div 2,2)$ & 18 & \\
\hline & Toplam & 192 & 183 & 375 & \\
\hline
\end{tabular}

*Gruplar arası fark p<.05 düzeyinde anlamlıdır

Tablo 6 incelendiğinde, 1 ila 4 saat arası tv izleyen öğrenci grubu, vandalizmin en yüksek olduğu ve en düşük olduğu grubu kapsamakta, diğer bir ifadeyle her iki ucu da bünyesinde barındırmaktadır. 1 saatten az veya 4 saatten fazla izleyenler ise orta grubu oluşturmaktadırlar.

\subsection{Altıncı Alt Amaca Yönelik Bulgular} (Findings Dealing with the Sixth Sub-objective)

Tablo 7'de öğrencilerin vandalist davranışlar sergilemelerinde günlük bilgisayar kullanım süreleri bakımından bir farklılık olup olmadığı test edilmiş, yapılan ki kare sonrasında şu bulgulara ulaşılmıştır.

Tablo 7. Günlük Bilgisayar Kullanım Süresi Bakımından Vandalist Davranışlarda Bulunma Sıklığı

(Table 7. Chi Square test results related vandalist dispotions according to the time allotted to using computer)

\begin{tabular}{|c|c|c|c|c|c|}
\hline & Süre & $\begin{array}{l}\text { Vandalist } \\
\text { davranışlar } \\
\text { düşük }\end{array}$ & $\begin{array}{l}\text { Vandalist } \\
\text { davranışlar } \\
\text { yüksek }\end{array}$ & Top. & $\mathrm{p}$ \\
\hline \multirow{4}{*}{$\begin{array}{l}\text { Günlük } \\
\text { Bilgisayar } \\
\text { Kullanlm } \\
\text { Süresi }\end{array}$} & 1 saatten az & $113(69,8)$ & $135(77,6)$ & 248 & \multirow{4}{*}{.093} \\
\hline & 1-4 saat arası & $40(24,7)$ & $36(20,7)$ & 76 & \\
\hline & 4 saatten fazla & $9(5,6)$ & $3(1,7)$ & 12 & \\
\hline & Toplam & 162 & 174 & 336 & \\
\hline
\end{tabular}

Tabloya göre, gruplar arası fark ( $\mathrm{p}=.093)$ beklenen farktan yüksek olduğundan (p>.05) null hipotez kabul edilmiştir, buna göre öğrencilerin vandalist davranişlar sergileme düzeyleri bilgisayar başında geçirdikleri süreden etkilenmemektedir.

\subsection{Yedinci Alt Amaca İlişkin Bulgular}

(Findings Dealing with the Seventh Sub-objective)

Tablo 8'de öğrencilerin ailelerini destekleyici olarak algılama durumları ile tv karşısında geçirdikleri sürelere ilişkin bilgilere yer verilmiştir. 
Tablo 8. Öğrencilerin günlük tv izleme süreleri bakımından aile ilişkisi algıları, tek yönlü anova testi sonuçları

(Table 8. One way anova results related to family relation perceptions in respect to time allotted to watching television)

\begin{tabular}{|c|c|c|c|c|c|c|c|}
\hline & Süre & $\mathrm{N}$ & $\overline{\mathrm{X}}$ & SS & F & $\mathrm{p}$ & Bonferonni \\
\hline \multirow{4}{*}{$\begin{array}{l}\text { Günlük } \\
\text { Tv } \\
\text { izleme } \\
\text { Süresi }\end{array}$} & 1 saatten az & 143 & 26,53 & 2,828 & \multirow{4}{*}{6,153} & \multirow{4}{*}{$.002 \star$} & \multirow{4}{*}{$\begin{array}{l}1-3 \\
2-3\end{array}$} \\
\hline & 1-4 saat arası & 205 & 26,22 & 3,415 & & & \\
\hline & 4 saatten fazla & 17 & 23,65 & 3,570 & & & \\
\hline & Toplam & 365 & 26,22 & 3,250 & & & \\
\hline
\end{tabular}

*Gruplar arası fark p<.05 düzeyinde anlamlıdır.

Tablodaki bulgulara dayanarak, ailelerini destekleyici olarak algılama bakımından en yüksek puan ortalamasına $(\overline{\mathbf{X}}=26,53)$ ile 1 saatten az tv izleyen öğrencilerin sahip olduğu görülmektedir, bu öğrencilerin ailelerini destekleyici olarak algılama durumları 4 saatten fazla tv izleyen öğrencilere göre $(\overline{\mathbf{X}}=23,65)$ daha yüksektir, aradaki fark anlamlıdır. Yine 1-4 saat arası tv izleyen öğrencilerin ailelerini destekleyici algılamaya yönelik algı puanları $(\bar{X}=26,22), 4$ saatten fazla tv izleyen gruba $(\bar{X}=23,65)$ kıyasla fazladır, aradaki fark anlamlıdır. 1saatten az izleyen öğrencilerle 1-4 saat arası izleyenler arasında anlamlı bir fark bulunmamıştır.

\subsection{Sekizinci Alt Amaca İlişkin Bulgular (Findings Dealing with the Eighth Sub-objective)}

Tablo 9'da öğrencilerin ailelerini destekleyici olarak algılama durumları ile bilgisayar kullanım sürelerine ilişkin bilgilere yer verilmiştir.

Tablo 9. Öğrencilerin günlük bilgisayar kullanım süreleri bakımından aile ilişkisi algıları, tek yönlü anova testi sonuçları

(Table 9. One way anova results related to family relation perceptions in respect to time allotted to watching television)

\begin{tabular}{|c|c|c|c|c|c|c|c|}
\hline & Süre & $\mathrm{N}$ & $\overline{\mathrm{X}}$ & SS & $\mathrm{F}$ & $\mathrm{p}$ & Bonferonni \\
\hline \multirow{4}{*}{$\begin{array}{l}\text { Bilgisayar } \\
\text { Kullanım } \\
\text { Süresi }\end{array}$} & 1 saatten az & 244 & 26,47 & 3,182 & \multirow{4}{*}{4,44} & \multirow{4}{*}{.012} & \multirow{4}{*}{$\begin{array}{l}1-3 \\
2-3\end{array}$} \\
\hline & 1-4 saat arası & 74 & 26,12 & 3,184 & & & \\
\hline & 4 saatten fazla & 11 & 23,55 & 4,547 & & & \\
\hline & Toplam & 329 & 26,29 & 2,267 & & & \\
\hline
\end{tabular}

Tablo 9'a göre, ailelerini destekleyici olarak algılama bakımından en yüksek puan ortalamasına $(\overline{\mathrm{X}}=26,47)$ ile 1 saatten az bilgisayar kullanan öğrencilerin sahip olduğu görülmektedir, bu öğrencilerin ailelerini destekleyici olarak algılama durumları 4 saatten fazla bilgisayar kullanan öğrencilere göre $(\overline{\mathrm{X}}=23,55)$ daha yüksektir, aradaki fark anlamlıdır. Yine 1-4 saat arası tv izleyen öğrencilerin ailelerini destekleyici algılamaya yönelik algı puanları $(\bar{X}=26,12), 4$ saatten fazla tv izleyen gruba $(\bar{X}=23,55)$ kıyasla fazladır, aradaki fark anlamlıdır. 1saatten az izleyen öğrencilerle 14 sat arası izleyenler arasında anlamlı bir fark bulunmamıştır.

\section{SONUÇ, TARTIŞMA VE ÖNERIILER}

(DISCUSSION, CONCLUSION AND RECOMMENDATIONS)

Horowitz ve Tobaly (2003), okula karşı tutumların, okuldaki algılanan vandalizm düzeyinin, öğretmenlere karşı tutumların ve okul kaygısının vandalizmle ilişkili olduğunu saptamışlardır. Öte yandan birinci alt probleme ilişkin bulgularla tutarlı olarak sınıf düzeyinin anlamıı etki yaratmadığını saptamışlardır. Ayrıca sosyal çevrenin 
vandalizmle ilişkisinin altını çizmişlerdir ki bu ikinci ve üçüncü alt amaca ilişkin bulgularla tutarlılık göstermektedir. Küçük bir çevreden öğrenci alan ve düşük sosyoekonomik düzeyli öğrencilerin yoğunlaştığı okulun (Okul 1) kendisine göre yüksek sosyoekonomik düzeye sahip diğer okullara kıyasla daha az vandalizme ev sahipliği yapıyor olması, üçünü alt probleme ilişkin bulgularla da tutarlıdır. Buna göre ailesinin aylık geliri 0-1000 aralığında olan öğrencilerin vandalist davranışları diğerlerinden daha azdır. Elde edilen bulgular ışığında, okuldaki öğrenci sayısının az olmasının tanınırlığı artırması ve homojen okul yapısının okula aidiyet hissini arttırması dolayısıyla vandalizmi azalttığı söylenebilir. Bu yorum, Flemington (1994) ve Mayer'in (1983) araştırma bulgularıyla tutarlıdır. Medley (1985:22) ise okul tahripçiliğinin nitelik ve niceliğinin okul boyutuyla ters orantılı olmasını, büyük okullarda tahribe açık daha fazla malın olmasından da göreceli olarak etkilendiğini belirtir.

Ceccato (2008) ve Taylor (1997) tarafindan ortaya konan aile etkisinin test edildiği beşinci alt probleme ilişkin bulgular, aile kabulunün düşük olarak algılandığı grupta vandalist davranışların daha çok görüldüğünü göstermektedir. Benzer şekilde Bartlett (1976:80-81)de aileye yönelik tutumları olumlu bireylerin içinde yaşadıkları kültürel çevreyle olumlu etkileşime girdiklerini tespit etmiştir. Literatüre ek olarak yüksek aile kabul algısının da vandalist davranışların yüksek olduğu grupta daha fazla olduğu saptanmıştır. Bu durum, ailelerin destekleyici görüntüsünün altında yanlış bir ebeveynlik tutumu olarak çocuğun her davranışını onaylama eğiliminin olmasından kaynaklanmış olabilir. Bu durumda çocuk ailesini destekleyici olarak algllar. Zira Richards (1976:112), ailenin, rol model olarak, çocuklarının gözlemleyici ve gözetleyicisi olarak, ebeveyn disiplinin ölçü ve ölçütleriyle teşvik edici ve caydırıcı birer faktör olabileceğini belirtir.

TV izleme düzeylerine göre vandalist davranışlarda bulunma sıklığının incelendiği beşinci alt problemde, elde edilen bulgular 1-4 saat arası tv izleyen öğrencilerin hem düşük hem yüksek vandalizm düzeyine diğer iki gruptan daha fazla sahip oldukları saptanmıştır. Öğrencilerin çoğunluğu 1-4 saat arası TV izlemektedirler ve daha sağlıklı yorumlar yapılabilmesi için sonraki araştırmalarda bu gruplama daha küçük parçalara bölünerek tekrarlanabilir. Yine tv izleme süresine göre öğrencilerin ailelerini algılama durumlarına bakıldığında tv izleme süresi arttıkça destekleyicilik algısının düştüğü görülmektedir. Aynı bulgular bilgisayar kullanım süresi için de geçerlidir. Tv ve bilgisayar kullanım süresinin artmasında aile ile geçirilen vaktin azalması, bu sonucun ortaya çıkmasına sebep olmuş olabilir.

\section{NOT (NOTICE)}

Bu çalışma 8-10 Haziran 2015 tarihlerinde Hacettepe Üniversitesi ve EJER tarafından düzenlenen 2. Uluslararası Avrasya Eğitim Araştırmaları Kongresinde özet bildiri olarak sunulmuştur.

\section{KAYNAKÇA (REFERENCES)}

- Arceneaux, R.J., (1976). A Study of Violence and Vandalism in the United States Public School System. Doktara Tezi, University of Southern California, California.

- Austin, D. and Sanders, C., (2007). Graffiti and perceptions of safety: A pilot study using photographs and survey data. Journal of Criminal Justice and Popular Culture, 14(4), 292-316. 
- Bartlett, K.F., (1976). A Self-reported Study of Participation in Vandalism by the Sophomore Classes of Three Selected Rural Ohio High Schools. Doktora Tezi, Ohio State University, Ohio.

- Bower, R., (1976). Vandalism in selected Florida schools. Doktora Tezi, Florida Atlantic University, Florida.

- Brown-Syed, C. and Owens, B.M., (2011). Roundup. Library \& Archival Security, 24 (2), 119-128.

- Ceccato, V., (2008). Expressive crimes in post-socialist states of Estonia, Latvia and Lithuania. Journal of Scandinavian Studies in Criminology and Crime Prevention, 9, 2-30.

- Couture, D.J., (1983). Vandalism in Wayne County public schools: a model for reporting and research. Doktora Tezi, Wayne state University, Michigan.

- Demirtaş Zorbaz, S. ve Korkut Owen, F., (2013). Çocuklar için aile ilişkileri ölçeği'nin geliştirilmesi. Türk Psikolojik Danışma ve Rehberlik Dergisi, 4(39), 58-67.

- Doğan, S. ve Demir, İ., (2012). Genel lise öğrencilerinin okul tahripçiliği algıları. Ahi Evran Üniversitesi Kırşehir Eğitim Fakültesi Dergisi (KEFAD), 13(1), 133-147.

- Erkuş, A., (2013). Bilimsel Araştırma Süreci (4. basım b.). Ankara: Seçkin Yayıncılık.

- Flemington, A.M.C., (1994). A study of comparing seventh-grade students' perceptions of factors related to a safe school environment at a partnership school and a non-partnership school. Doktora Tezi, Pepperdine University, California.

- Goldstein, A.P., (1996). The psychology of vandalism. New York: Springer Science +Business Media.

- Horowitz, T. and Tobaly, D., (2003). School vandalism: Individual and social context.Adolescence, 38(143), 131-139.

- Jimerson, S.R. and Furlong, M.J., (2006). The handbook of school violence and school safety. Oxford: Elsevier.

- Kaiser, C., (1972). Factors relating to vandalism in Detroit public elementary schools. Doktora Tezi, Wayne state University, Michigan.

- Macario, R., Marquez, P., and Ramos, A., (2004). How to improve personal security in public transport. Public Transport International. 53(5) . 18-20.

- Massey, M., (1997). A study of teachers' and administrators' perception of high school violance and vandalism: Contributing factors and successful practices. Doktora Tezi, George Vashington University.

- Mayer, G.B.A., (1983). Preventing school vandalism and improving discipline: a three-year study. Journal of applied behavior analysis, $16(4), 355-369$.

- Oruç, M., (2008). Yönetici, öğretmen ve öğrenci görüşlerine göre Ankara ili genel lise ve meslek lisesi öğrencilerinin okul malına karşı gösterdikleri tahripçi davranışlar. Yüksek Lisans Tezi, Ankara Üniversitesi Eğitim Bilimleri Enstitüsü, Ankara.

- Owinyo, S.N., (2006). Caught in-between: Exploring the complexities of school vandalism. case study research in Kenya. Doktora Tezi, Katholieke Universiteit Leuven, Belçika.

- Plavnick, S., (1983). School violence and vandalism: Fears, fallacies, and facts. Doktora tezi, Michigan state University, Michigan. 
- Reade, E., (1982). Residential decay, household movement and class structure ( Britain). Policy and Politics, 10(1), 27-45.

- Richards, P., (1976). Patterns of middle class vandalism: A case study of suburban adolescents. Doktora Tezi, Northwestern University, Illinois.

- Stretton, E., (1977). A Study of School Vandalism In Junior High Schools and Middle Schools in The State of Indiana. Doktora Tezi, Indiana Uiversity, Indiana.

- Taylor, D., (1997). Family factors, theft, vandalism, and major deviance among a multiracial/multiethnic sample of adolescent girls. Journal of Social Distress and the Homeless, 6(1), 71-87.

- Yavuzer, Y., (1998). Niğde İlindeki Öğretmenlerin Okul Tahripçiliğine Karşı ideolojik Yönelimleri. Yüksek Lisans Tezi, Ankara Üniversitesi, Ankara. 